\title{
Physico-Mechanical Properties of Wood and Non-Wood Plaster of Paris Bonded Composite Ceiling Boards
}

\section{Temidayo Emmanuel Omoniyi ${ }^{1}$, Kenny Ajobiewe ${ }^{1}$}

\author{
${ }^{1}$ University of Ibadan \\ Ibadan, Oyo State, 900001, Nigeria
}

DOI: $10.22178 /$ pos. $58-9$

LCC Subject Category: TH6014-6081

Received 23.04.2020

Accepted 28.05.2020

Published online 31.05.2020

Corresponding Author:

Temidayo Emmanuel Omoniyi

temidayoomoniyi@gmail.com

(c) 2020 The Authors. This article

is licensed under a Creative Commons

Attribution 4.0 License @) (1)

\begin{abstract}
Woody (Alzibia zygia) and Non-woody (rattan and yarn strands) fibres were used comparatively to improve the physicomechanical properties of Plaster of Paris bonded composite which is used as ceiling boards. The addition of fibre reinforcement in a discrete form improves the engineering properties of the Plaster of Paris. The woody and nonwoody residues were varied in $10,20,30,40$, and $50 \%$ of the whole mix while the Plaster of Paris used were in the ratio 100 (control), 90, 80, 70,60 , and $50 \%$. The mean density of the composite produced is 3250 $\mathrm{kg} / \mathrm{m} 3$. The mean thickness swelling after 2 and 24 hours is $0.84 \%$ and $0.88 \%$ respectively with the mean water absorption at $13.8 \%$ after 2 hours and $16.2 \%$ after 24 hours. The MOR and MOE of the composites produced ranged from $1.21-1.22 \mathrm{~N} / \mathrm{mm}^{2}, 2431-51488 \mathrm{~N} / \mathrm{mm}^{2}$ for sawdust, $1.17-1.22 \mathrm{~N} / \mathrm{mm}^{2}, 10027-49940 \mathrm{~N} / \mathrm{mm}^{2}$ for yarn strands and $1.20-$ $1.22 \mathrm{~N} / \mathrm{mm}^{2}, 23566-86210 \mathrm{~N} / \mathrm{mm}^{2}$ for the rattan strands. The results showed physicomechanical properties of POP-bonded fibre reinforced composites were increased for both wood and non-wood fibres and rattan strands compared best.
\end{abstract}

Keywords: Wood composites; Physico-mechanical; Fibre reinforcement; Plaster of Paris; Ceiling board.

\section{INTRODUCTION}

Reinforced Plaster of Paris Composite ceiling boards is a new decorative and finishing material that is gaining increasing importance and usage. Plaster of Paris or gypsum is a very soft sulfate mineral of chemical formulae $\mathrm{CaSO}_{4} 2 \mathrm{H}_{2} \mathrm{O}$ which presents itself often as monoclinic, massive, flat, or elongated and generally prismatic crystals with its colour ranging from colorless to white [1]. In recent years, asbestos materials for making ceiling boards have been banned in many advanced countries due to its carcinogenic nature, with agencies in construction industries having identified its real and potentially adverse effect on humans [2]. Locally sourced building materials that would facilitate sustainable development remain underdeveloped to a socially and economically acceptable level, owing to the low level of development of the economy [3].

Authors [4] reported that composite is designed to take advantage of the desirable characteristics of constituent materials by choosing an appropriate combination of matrix and reinforcement material, thus producing a new material that meets the exact requirements of a particular application. Yarn is a long continuous length of interlocked fibres suitable for use in the production of textiles, sewing, crocheting, knitting weaving, embroidery, and rope making, while rattan is a stick made from the stem of the rattan palms. Rattan canes are numbered among the important commercial non-timber forest products employed in the furniture industry in the tropics, however, over $30 \%$ of rattan harvested at any time particular for furniture manufacture are wastes [5]. Alzibia zygia is a deciduous tree nine to thirty meters tall with a spreading crown and a graceful architectural form and its bole tall and clear, around $240 \mathrm{~cm}$ in diameter. It has a dark grey and smooth surface [6]. These materials experimented as reinforcement to improve the properties of Plaster of Paris to produce durable, affordable, and environmentally friendly (noncarcinogenic substances) material suitable structurally as ceiling boards. 


\section{METHODOLOGY}

Materials Collection. Sawdust of Alzibia zygia collected from the Bodija plank market in Ibadan was graded and sieved to remove impurities, then oven-dried to around $101^{\circ} \mathrm{C}$ to reduce the moisture content of the fibre. Rattan, yarn fibres and Plaster of Paris were purchased from a retail outlet also in Ibadan.

Procedure. The materials were then weighed and batched in accordance to the research methods (Tables 1, 2, and 3). The mixing was done manually with potable water and added into a prepared wooden mold. The mixture was allowed to sit for some minutes before curing take place. The produced composite materials were then subjected to the test to investigate their physical and mechanical properties (Table 1-3).

Table 1 - Plaster of Paris and Alzibia zygia (Ayunre)

\begin{tabular}{|c|c|c|c|}
\hline Samples & $\begin{array}{c}\text { POP } \\
(\%)\end{array}$ & $\begin{array}{c}\text { Wood fibre } \\
(\%)\end{array}$ & $\begin{array}{c}\text { Samples } \\
\text { produced }\end{array}$ \\
\hline PWF1 & 100 & 0 & 3 \\
\hline PWF2 & 90 & 10 & 3 \\
\hline PWF3 & 80 & 20 & 3 \\
\hline PWF4 & 70 & 30 & 3 \\
\hline PWF5 & 60 & 40 & 3 \\
\hline PWF6 & 50 & 50 & 3 \\
\hline
\end{tabular}

$P W F=P O P+$ woof fibre

Table 2 - Plaster of Paris and Rattan fibre

\begin{tabular}{|c|c|c|c|}
\hline Samples & $\begin{array}{c}\text { POP } \\
(\%)\end{array}$ & $\begin{array}{c}\text { Rattan fibre } \\
(\%)\end{array}$ & $\begin{array}{c}\text { Samples } \\
\text { produced }\end{array}$ \\
\hline PRF1 & 100 & 0 & 3 \\
\hline PRF2 & 90 & 10 & 3 \\
\hline PRF3 & 80 & 20 & 3 \\
\hline PRF4 & 70 & 30 & 3 \\
\hline PRF5 & 60 & 40 & 3 \\
\hline PRF6 & 50 & 50 & 3 \\
\hline
\end{tabular}

$P R F=P O P+$ rattan fibre

Table 3 - Plaster of Paris and yarn fibre

\begin{tabular}{|l|c|c|c|}
\hline Samples & $\begin{array}{c}\text { POP } \\
(\%)\end{array}$ & $\begin{array}{c}\text { Rattan fibre } \\
(\%)\end{array}$ & $\begin{array}{c}\text { Samples pro- } \\
\text { duced }\end{array}$ \\
\hline PYF1 & 100 & 0 & 3 \\
\hline PYF2 & 90 & 10 & 3 \\
\hline PYF3 & 80 & 20 & 3 \\
\hline PYF4 & 70 & 30 & 3 \\
\hline PYF5 & 60 & 40 & 3 \\
\hline PYF6 & 50 & 50 & 3 \\
\hline
\end{tabular}

$P Y F=P O P+$ yarn fibre
The following tests were carried out on the specimens.

Density. After curing, the samples were weighed on a digital weighing scale and their corresponding weight in kilograms was recorded. The density of the materials was calculated with the following equation (1):

$$
\partial=\frac{w}{v},
$$

where $\partial$ is the density in $\left(\mathrm{kg} / \mathrm{m}^{3}\right)$;

$w$ is the weight of the composite produced;

$v$ is the volume of the produced composite.

Specific gravity. The specific gravity was calculated using this equation (2):

$$
S G=\frac{\partial c}{\partial w}
$$

where $S G$ is the specific gravity of samples;

$\partial c$ is the density of composites produced

$\left(\mathrm{kg} / \mathrm{m}^{3}\right)$;

$\partial w$ is the density of water in $\left(1000 \mathrm{~kg} / \mathrm{m}^{3}\right)$.

Water Absorption and Thickness swelling. The specimen from each specimen was submerged horizontally under $50 \mathrm{~mm}$ of distilled water maintained at a room temperature of about $27^{\circ} \mathrm{C}$. The amount of water absorbed after 2 hours and 24 hours were recorded.

$$
\% \text { water }=\frac{w_{2}-w_{1}}{w_{1}} \times 100,
$$

$\mathrm{w}_{1}$ and $\mathrm{w}_{2}$ is the initial and final weight before and after soaking respectively.

$$
\% \text { thickness swelling }=\frac{t_{2}-t_{1}}{t_{1}} \times 100,
$$

$t_{1}$ and $t_{2}$ is the initial and final thickness before and after soaking.

Modulus of Rupture (MOR). This was conducted to approximate the bending strength of the produced composite materials. The samples were tested using the universal test machine (UTM) of the Department of Agricultural and Environmental Engineering, University of Ibadan. 


$$
M O R=\frac{3 P L}{2 B H^{2}},
$$

where $P$ is the maximum force/ load in $(\mathrm{N})$;

$L$ - span of the board (mm);

$B$ - width of the test specimen (mm);

$\mathrm{H}$ - thickness of the test specimen (mm).

Modulus of Elasticity (MOE):

$$
M O E=\frac{P L^{3}}{4 D B H^{3}},
$$

where $P$ is the maximum force / load in $(\mathrm{N})$;

$L$ - span of the board (mm);

$B$ - width of the test specimen (mm);

$H$ - thickness of the test specimen (mm);

$D$ - deflection at mid-point.

\section{RESULTS AND DISCUSSION}

Density and specific gravity. Figure 1-2 shows the produced composite materials.

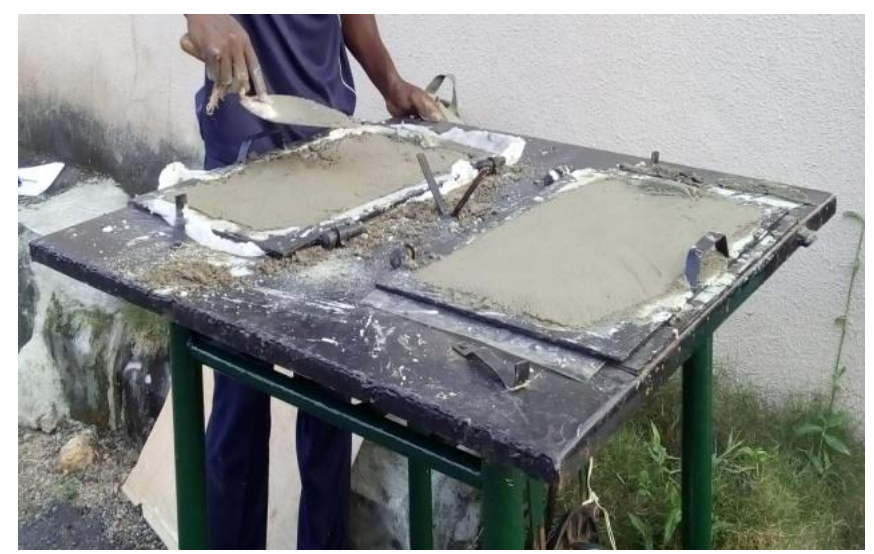

Figure 1 - Producing samples with Vibrating table

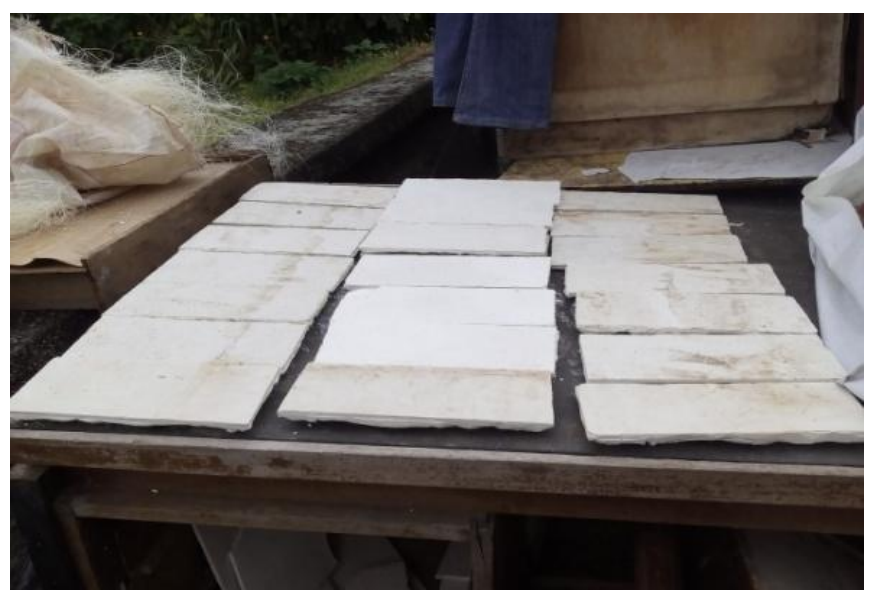

Figure 2 - Samples of the fibre composites

Table 4 shows the densities and specific gravity of the material produced. The densities varies from $3200 \mathrm{~kg} / \mathrm{m}^{3}$ to $3900 \mathrm{~kg} / \mathrm{m}^{3}$ (wood fibre), $2700 \mathrm{~kg} / \mathrm{m}^{3}$ to $4500 \mathrm{~kg} / \mathrm{m}^{3}$ (rattan fibre), $2000 \mathrm{~kg} / \mathrm{m}^{3}$ to $4500 \mathrm{~kg} / \mathrm{m}^{3}$ (yarn fibre) and $4700 \mathrm{~kg} / \mathrm{m}^{3}$ (POP only). Samples produced with POP alone have higher densities due to the presence of reinforced fibres (which tends to be lighter) in other samples. Increase in the fibre content of the composite produced decreases the density and specific gravity of the material which is in accordance to the report on wood composite by [5].

Thickness Swelling and Water Absorption. Table 5 and 6 shows the water absorption and thickness swelling percentage of the composite materials respectively. Cumulatively, the higher the fibre content in the composite, the higher the water absorption, which may be due to the hydrophilic nature of the wood and the other fibres.

Table 4 - Density and specific gravity of composites

\begin{tabular}{|c|c|c|c|c|c|c|}
\hline $\begin{array}{c}\text { Sample, } \\
\text { Pop/fibre }\end{array}$ & $\begin{array}{c}\partial_{\mathrm{PWF}} \\
\left(\mathrm{kg} / \mathrm{m}^{3}\right)\end{array}$ & $\begin{array}{c}\partial_{\mathrm{PRF}} \\
\left(\mathrm{kg} / \mathrm{m}^{3}\right)\end{array}$ & $\begin{array}{c}\partial_{\text {PYF }} \\
\left(\mathrm{kg} / \mathrm{m}^{3}\right)\end{array}$ & SG $_{\mathrm{PWF}}$ & SG $_{\mathrm{PRF}}$ & $S_{\text {PYF }}$ \\
\hline $100 / 0$ & 4700 & 4700 & 4700 & 4.7 & 4.7 & 4.7 \\
\hline $90 / 10$ & 3900 & 4500 & 4500 & 3.9 & 4.5 & 4.5 \\
\hline $80 / 20$ & 3500 & 4000 & 3500 & 3.5 & 4 & 3.5 \\
\hline $70 / 30$ & 3480 & 3000 & 3200 & 3.48 & 3 & 3.2 \\
\hline $60 / 40$ & 3320 & 3100 & 2700 & 3.32 & 3.1 & 2.7 \\
\hline $50 / 50$ & 3200 & 2700 & 2000 & 3.2 & 2.7 & 2 \\
\hline
\end{tabular}

The behaviour of the produced composites was similarly reported by [8], that the presence of hydroxyl groups inside the cellulose and hemicelluloses attract the water molecules and form hydrogen bonding. Moreover, due to the porous structure of wood fibres, the composites with higher wood content absorb more water which penetrates into the pores according to the principle of capillary flow. The yarn fibre absorbed the lowest amount of water content. 
Table 5 - Water absorption (\%) of composites produced

\begin{tabular}{|l|c|c|c|c|c|c|}
\hline Sample & $\begin{array}{c}\text { \%WA } \\
(2 \mathrm{hrs})\end{array}$ & $\begin{array}{c}\text { \%WA } \\
(24 \mathrm{hrs})\end{array}$ & $\begin{array}{c}\text { \%WA } \\
(2 \mathrm{hrs})\end{array}$ & $\begin{array}{c}\text { \%WA } \\
(24 \mathrm{hrs})\end{array}$ & $\begin{array}{c}\text { \%WA } \\
(2 \mathrm{hrs})\end{array}$ & $\begin{array}{c}\text { \%WA } \\
(24 \mathrm{hrs})\end{array}$ \\
\hline $100 / 0$ & 11.53 & 15.2 & 11.55 & 15.23 & 11.63 & 11.24 \\
\hline $90 / 10$ & 14.87 & 15.75 & 13.98 & 14.24 & 12.32 & 12.94 \\
\hline $80 / 20$ & 15.06 & 16.98 & 14.28 & 14.93 & 12.72 & 13.19 \\
\hline $70 / 30$ & 15.47 & 18.78 & 14.72 & 15.34 & 13.01 & 13.89 \\
\hline $60 / 40$ & 15.90 & 19.22 & 14.84 & 15.45 & 13.59 & 14.14 \\
\hline $50 / 50$ & 15.98 & 20.02 & 15.77 & 16.32 & 14.34 & 15.21 \\
\hline
\end{tabular}

Table 6 - Thickness swelling (\%) of composites

\begin{tabular}{|l|c|c|c|c|c|c|}
\hline Sample & $\begin{array}{c}\text { \%TSPWF } \\
(2 \mathrm{hrs})\end{array}$ & $\begin{array}{c}\text { \%TSPWF } \\
(24 \mathrm{hrs})\end{array}$ & $\begin{array}{c}\text { \%TSPRF } \\
(2 \mathrm{hrs})\end{array}$ & $\begin{array}{c}\text { \%TSPRF } \\
(24 \mathrm{hrs})\end{array}$ & $\begin{array}{c}\text { \%TSPYF } \\
(2 \mathrm{hrs})\end{array}$ & $\begin{array}{c}\text { \%TSPYF } \\
(24 \mathrm{hrs})\end{array}$ \\
\hline $100 / 0$ & 0.39 & 0.59 & 0.39 & 0.59 & 0.39 & 0.59 \\
\hline $90 / 10$ & 0.58 & 0.78 & 0.48 & 0.69 & 0.40 & 0.58 \\
\hline $80 / 20$ & 0.77 & 0.88 & 0.51 & 0.78 & 0.58 & 0.59 \\
\hline $70 / 30$ & 0.96 & 1.18 & 0.76 & 0.98 & 0.58 & 0.67 \\
\hline $60 / 40$ & 1.28 & 1.57 & 0.98 & 1.13 & 0.77 & 0.98 \\
\hline $50 / 50$ & 1.35 & 1.96 & 1.17 & 1.23 & 0.79 & 0.99 \\
\hline
\end{tabular}

Table 6 shows the results of the thickness swelling test. Generally, the change in thickness of the produced composites is very minimal after 2 and 24 hours. The yarn fibre has the best performance under the thickness swelling test. As reported by [2] increase in the fibre ratio of the composites increases the thickness swelling after water immersion.

Modulus of Elasticity (MOE) and Modulus of Rupture (MOR). The strength properties of the composites were shown in table 7. The introduction of fibre tends to increase the Modulus of Elasticity of the composites as the primary objective of fibres as filler is to increase the stiffness of WPC. The results tally with [9] report, in which the ten- sile and flexural strength slightly increased with an increasing wood fibre content of a WPC. The rattan fibre reinforced composites has the highest range of MOE values of $40167 \mathrm{KN} / \mathrm{mm}^{2}$ to $50982 \mathrm{KN} / \mathrm{mm}^{2}$, wood filler composites has a range of $39310 \mathrm{KN} / \mathrm{mm}^{2}$ to $43477 \mathrm{KN} / \mathrm{mm}^{2}$, and the yarn filler composites range from 39567 $\mathrm{KN} / \mathrm{mm}^{2}$ to $43270 \mathrm{KN} / \mathrm{mm}^{2}$. The composites exhibit the same behaviour for the MOE and MOR test. The rattan performs best with MOR values of $1.221 \mathrm{KN} / \mathrm{mm}^{2}$ to $1.229 \mathrm{KN} / \mathrm{mm}^{2}$, wood fibre ranges from $1.221 \mathrm{KN} / \mathrm{mm}^{2}$ to $1.229 \mathrm{KN} / \mathrm{mm}^{2}$, and yarn fibre ranges from $1.219 \mathrm{KN} / \mathrm{mm}^{2}$ to $1.211 \mathrm{KN} / \mathrm{mm}^{2}$.

Table 7 - Results of MOE and MOR

\begin{tabular}{|l|c|c|c|c|c|c|}
\hline Sample & $\begin{array}{c}\text { MOE } \\
\left(\mathrm{KN} / \mathrm{mm}^{2}\right)\end{array}$ & $\begin{array}{c}\mathrm{MOE} \\
\left(\mathrm{KN} / \mathrm{mm}^{2}\right)\end{array}$ & $\begin{array}{c}\mathrm{MOE} \\
\left(\mathrm{KN} / \mathrm{mm}^{2}\right)\end{array}$ & $\begin{array}{c}\mathrm{MOR} \\
\left(\mathrm{KN} / \mathrm{mm}^{2}\right)\end{array}$ & $\begin{array}{c}\mathrm{MOR}_{\text {PRF }} \\
\left(\mathrm{KN} / \mathrm{mm}^{2}\right)\end{array}$ & $\begin{array}{c}\mathrm{MOR}_{\text {PYF }} \\
\left(\mathrm{KN} / \mathrm{mm}^{2}\right)\end{array}$ \\
\hline $100 / 0$ & 32142.9 & 32142.9 & 32142.9 & 1.210 & 1.210 & 1.210 \\
\hline $90 / 10$ & 39310.1 & 40167.38 & 39567.39 & 1.221 & 1.284 & 1.219 \\
\hline $80 / 20$ & 41488.0 & 45235.11 & 41678.78 & 1.224 & 1.297 & 1.219 \\
\hline $70 / 30$ & 42757.9 & 56567.76 & 41997.98 & 1.237 & 1.307 & 1.227 \\
\hline $60 / 40$ & 43038.9 & 51709.78 & 43018.78 & 1.228 & 1.375 & 1.211 \\
\hline $50 / 50$ & 43477.7 & 50982.77 & 43270.77 & 1.229 & 1.376 & 1.228 \\
\hline
\end{tabular}

\section{CONCLUSION}

Fibre-POP composites was produced from wood (Alzibia zygia), rattan (Laccosperma secundiflorum), and yarn. The composites were tested for strength and physical properties. The results derived implied that:
1. The mechanical properties of Rattan reinforced composite in terms of Modulus of Rupture and Modulus of Elasticity has the highest value meaning that bending strength of rattan reinforced composite is high. 
2. The use of fibre to reinforce Plaster of Paris considerably increased the strength properties of the material.
3. There is reduction in environmental pollution through the use of waste fibres to yield a material suitable in ceiling board production.

\section{REFERENCES}

1. Migneault, S., Koubaa, A., Erchiqui, F., Chaala, A., Englund, K., \& Wolcott, M. P. (2009). Effects of processing method and fiber size on the structure and properties of wood-plastic composites. Composites Part A: Applied Science and Manufacturing, 40(1), 80-85. doi: 10.1016/j.compositesa.2008.10.004

2. Ajayi, B. (2006). Properties of maize-stalk-based cement bonded composite. Forest Product Journal, 56(6), 51-56.

3. Popovic, F., Filipovic, J., \& Bozanic, V. (2013). Paradigm shift needed - municipal solid waste management in Belgrade, Serbia. Hemijska Industrija, 67(3), 547-557. doi: 10.2298/hemind120620087p

4. Omoniyi, T. E. , Alabi, O. J. (2017). Performance evaluation of a single screw extruder for the production of WPC. Forestry Association of Nigeria: n. d.

5. Olorunnisola, A. O., \& Agrawal, S. (2015). Effect of NaOH concentration and fibre content on the physic mechanical properties of cement bonded rattan fibre composite. Retrieved from https://pdfs.semanticscholar.org/a5d0/e1606e3b994e65576cccf991b59f864dc29b.pdf?_ga=2. 137225392.1488894276.1591557453-1042230176.1581878685

6. Orwa, C., Mutua, A., Kindt, R., Jamnadass, R., \& Anthony, S. (2009). Agroforestree Database: a tree reference and selection guide version 4.0. Retrieved from https://www.feedipedia.org/node/1650

7. Forest Products Laboratory. (2010). Wood Handbook. Retrieved from https://www.fpl.fs.fed.us/documnts/fplgtr/fpl_gtr190.pdf

8. Bledzki, A. K., Reihmane, S., \& Gassan, J. (1998). Thermoplastics Reinforced with Wood Fillers: A Literature Review. Polymer-Plastics Technology and Engineering, 37(4), 451-468. doi: 10.1080/03602559808001373

9. Stark, N., \& Rowland, R. (2003). Effects of wood fiber characteristics on mechanical properties of wood/propylene composites. Wood and Fibre Science, 35(2), 167-174. 